\title{
THE IMPLICATION OF BACK PROJECTION THEORY ON AL-SILSILAH AL-DHAHABIYYAH ISNAD
}

\author{
Abdul Hakim Wahid \\ Syarif Hidayatullah State Islamic University (UIN) Jakarta \\ hakim.wahid@uinjkt.ac.id \\ Bustamin \\ Syarif Hidayatullah State Islamic University (UIN) Jakarta \\ bustamin@uinjkt.ac.id
}

\begin{abstract}
One of hadith isnad that categorized as al-Asanid al-Dhahabiyyah (golden chain) is an Isnad path of Malik from Nāfi' from Ibn Umar from the Prophet, that is recognized as the most authentic isnad by the Muslim scholar. However, Juynboll state that In the Lisan literally hundreds of forged hadiths are listed supported by this isnad. By examining the path of transmission of hadiths using that isnad in Lisan al-Mizan book, the author of this paper finds that the number of false isnads using the pathway had no effect on the credibility of the transmission of the golden chain in the canonical books.
\end{abstract}

Keywords: Hadith, Isnad, Back Projection, Golden Chain

\section{Introduction}

According to hadith scholars, there are several series of isnads called as al-Silsilah al-Dhahabiyyah (golden chain). The criteria are varied, some are based on the name of a companion that is as al-Bukhari's remarks that Abu Hurayrah's reliable isnad is Abu al-Zinād from al-A'raj, while al-Hākim argues that the most reliable is al-Zuhri from Sa'id bin alMusayyab from Abu Hurairah. Al-Hakim also declared that Anas bin Mālik's reliable's isnad is Mālik from al-Zuhri, and the reliable of 'Umar bin al-Khattab is al-Zuhri from Sālim from Ibn' Umar. This opinion was agreed by Ishāq ibn Rāhawayh and Ahmad ibn Hanbal, while the Aishah's reliable isnad is 'Ubaid Allah bin' Umar from al-Qāsim (Al-'Iraqy).

In addition to those mentioned, the golden isnad that believed by the experts of hadith is the isnad of Malik from Nāfi' from Ibn 'Umar from the Prophet Muhammad (alBukhari) (Ibn Șalāḥ, 1986), the transmission of al-Zuhri from Sālim from Ibn' Umar, as well as the transmission of Muhammad bin Sirin from 'Ubaydah from Ali ibn Abi Tālib, as well as al-Zuhri's transmission from Ali bin Husayn from Husayn from Ali ibn Abi Tālib, and the narration of al-A'mash from Ibrahim from 'Alqamah from Ibn Mas'ūd (al- Nawawī, 1985). The diagram is below:
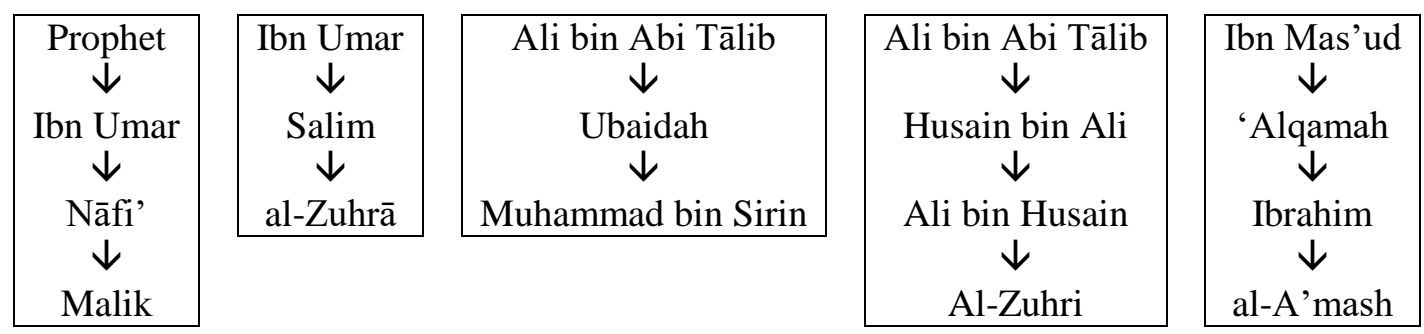

Despite the high degree of isnad with the path mentioned, Juynboll said that he found hundreds of false traditions with isnad Malik from Năfi 'from Ibn Umar. This 
opinion is based on his findings in Ibn Hajar's Lisān al-Mīzān. Juynboll said "In the Lisān literally hundreds of forged isnād (Juynboll, 1985). In his article on the position of Nāfi' the Mawla of Ibn Umar, Juynboll makes 3 major conclusions namely; first, that the hadith of the Prophet with the isnad Nāfi' from Ibn Umar contained in the canonical book is not returned to Năfi' but the majority returned to Malik ibn Anas. Second, the student and teacher relationship between Malik and Nāfi' contained in the biographical literature of Muslim's book, does not have a strong historical basis. Thirdly, the traditions contained in the canonical book with the Nāfi' isnad from Ibn Umar narrated by Nāfi' disciples, without exception are the traditions fabricated by the author of the book or by his teacher. Therefore, this article wants to prove the truth of Juynboll's findings in the Lisān al- Mìzān by applying the theories of Muslim hadith scholars.

\section{Methods}

The concept of "Isnad Backgrowth" has been recognized and accepted by the modern scholar (Brown, 2007), which indirectly reinforces the assumption of false prophetic traditions in canonical books compiled in the second half of the Hijri century. With regard to the golden isnad of Malik from Nāfi' from Ibn Umar, Juynboll found that hundreds of false hadiths had been propped up on this isnad. He concludes this by quoting the Lisān al-Mīzān book compossed by Ibn Hajar al-'Asqalāni, and according to him, these false traditions have existed since the life of Mālik (90-179), so the man so- called forger is Malik bin Anas (Juynboll, 1985). Meanwhile while the number of traditions narrated by Malik in the canonical book is very numerous. If everything is a false hadith, then it is enough to serve as an argument of Muslim scholars critical method weakness in hadith selection.

The Juynboll's statement is not entirely wrong, but instead shows the reliability of the method of criticism of Muslim hadith's scholars in an attempt to separate authentic hadiths with false ones, where the hadith with the golden isnad also needs to be examined if those who deliver it are less credible. But what should be considered counterfeiters is not Malik, or Năfi' which is considered fictitious, but the person who takes the narration from them both, or the people afterwards who also spread the hadith. Al-Khatib al-Baghdadi exemplifies the Gharib hadith on which he relied on this golden isnad, but his concern was the narrator to Abdullah bin Ibrahim al-Ghifāri who only narrated the hadith alone (al-Hamdhānī, 2002).

In response to Juynboll's findings above, the authors followed what they discovered and observed these traditions and found 161 da'if (weak) hadith narrated by this isnad. But before drawing further conclusions, it would be preferable to explain the Lisān al-Mīzān book and its contents firstly before explaining the position of those traditions.

Ibn Hajar said in his muqaddimah of Lisān al-Mīzān by explanation that after the Companions, there were those who did not have ability to convey the hadith of the Prophet, so they made a mistakes for what they narrated, Then Allah created a group of people from the Ummah to defend the Prophet's hadith, and they talked the personal narrator of the hadith with the purpose of counsel not for disgraceful critics, so that in the future there are books that contain the names of persons with disabilities in the narration of the hadith. And for the purpose of compiling the names of the weak peoples, the Lisān al-Mizān is written, with reference to Mìzān al-I'tidāl book by al-Dhahabī, without mentioning the names of narrators in the six canonic book of the hadith (Ibn Hajar 1971). In his book Ibn Hajar mentions the names of those who narrated the hadith with this isnad and mentioned his position by relying largely on Al-Dāruqutni's opinion in judging the credibility of the hadith narrator. Therefore, it's very reasonable to find hundreds of false hadiths related to golden chain Malik $\rightarrow$ Nāfi' $\rightarrow$ Ibn Umar in that book. 


\section{Result and Discussion}

From the research on Lisan al-Mīzān book, it was found the narrators whose traditions are unacceptable even though he narrated the hadith with Malik's golden chain, it is concluded here that Schacht's projecting back theory did occur in some of the hadith transmissions, but not so in al-Sahihayn book. In the two books, Schacht's projecting back theory cannot be found. The findings in Lisan al-Mīzann have added to the reliability of the Muslim scholar's method criticism in separating the rejected hadith by using research into its isnad. To prove the truth of this statement, the author will present a sample of the hadith selected as much as 10 percent of those contained in Lisan al-Mīzann so the total is 16 hadiths or narrations described as follows:

1. The transmission of Bakr Ibn al-Husayn Ibn Ali al-'Uthmānī, one of hadith he spreads is: Innamā Mathalu Șāhib al-Qur'ān ka Mathali al-Ibil al-Mu'allaqah. This hadith is also found in Sahih Muslim with the isnad of Yahya bin Yahya from Malik of Nāfi' from Ibn Umar (Muslim, 1993), Then in Sunan al-Nasā'i with a narration of Qutaibah from Malik from Nāfi' from Ibn Umar (Al-Nasā'̂̄, 1986). This isnad transmission line is authentic, the subject of Ibn Hajar's talk in Lisān is Bakr Ibn al-Husayn Ibn al-'Uthmānī, because there is a disconnect isnad, between al-Bāqilāni and al-Qa'nabī that should be two narrators (Ibn Hajar, 1971). So the hadith with this path cannot be used as a reference.

2. The transmission of Bakr Ibn Abdillah Ibn al-Sharūd al-Șan'ān̄̄, he was considered $d a$ ' $f$ (weak) by the hadith critics. One of the hadith which he spreads is as follows: Man Shariba Muskiran lam Tuqbal Șalātuhu mā Dāma fì Baṭihi minhu Qațrah. Bakr bin alSharud is not on the disciples list of who narrated the hadith from Malik as al-Mizzi listed, no one of the six canonical books compiler who mentioned him.

3. The transmission of Ibrahim bin Ishaq bin Nakhroh al-San'ani, one of the narrations he distributed is: Man Kabbara Takbīratan fì Sabìlillah Kānat Sahrah fì Mīzānih. This hadith is narrated from Abdullah bin Nāfi' from Malik from Nāfi' from Ibn Umar. According to al-Dāruqutnī, this hadith is mawdu' (false) because another Abdullah bin Nāfi' are majhul (unknown), and according to Ibn Hajar, the hadith of Ibrahim bin Ishaq has been narrated by Ibn Hibban in the group of weak people (Ibn Hajar, 1971).

4. The transmission of Ibrahim bin Zaid al-Aslamī al-Taflīsi, he narrated from al-Hasan bin Muhammad from Muhammad bin Idris al-Asbihani from Ahmad ibn Said from Jarir from Malik from Nāfi' from Ibn Umar. According to Abu Naim al-Asbihani, Ibrahim bin Zaid al-Taflisi has spoken on behalf of Malik and Ibn Lahi'ah with a forger hadiths (Ibn Hajar, 1971). One of the narration he distributes are: Șinfāni min Ummatī Laysa lahumā fì al-Islām Nasīb al-Qadariyyah wa al-Rāfị̣ah. According to al-Dāruquṭn̄ and Ibn Hibban, Zaid alAslamī narrates from Malik something that has no basis. This hadith is also recorded in sunan al-Tirmidhi with the narrations of Wāṣil Ibn Abd al-A'lā al-Kūfì from Muhammad bin Fuḍail from al-Qasim Ibn Ḥabīb and Ali bin Nizār from Nizār from 'Ikrimah from Ibn Abbas, with different texts. This hadith mentioned two groups; Qadariyyah and Rafidah, then in the narration of al-Tirmidhi, the two groups are Murji'ah and Qadariyyah with additional explanation that the hadith predicate is Hasan Gharib (al-Tirmidhi, 1975). This hadith is also recorded in Sunan Ibn Mājah with a text whose a similar meaning to al-Tirmidhi's, but using a transmission line from Muhammad bin Ismail al-Rāzī from Yunus bin Muhammad from Abdullah bin Muhammad al-Laithi from Nizār bin Ḥayyān from 'Ikrimah from Ibn Abbas and Jabir ibn Abdillah (Ibn Mājah). And from the searching on various hadith books, there is no one of that compiler who used Ibrahim bin Zaid al-Taflisi isnad.

5. The transmission of Ibrahim Ibn Musa al-Marwazi, he narrated from Malik from Nāfi' from Ibn Umar. One narrations he distributed is: Talab al- 'Ilm Farị̣ah. According to Ibn Hanbal, This hadith with this isnad is false or it's matan has a weak path (Ibn Hajar, 1971). This hadith is recorded in Sunan Ibn Mājah with a transmission from Hishām bin 
'Ammār from Hafṣ bin Sulaiman from Kathīr bin Shinzīr from Muhammad bin Sīrīn from Anas bin Malik from Prophet SAW. Muhammad Fu'ad Abd al-Bāqī commented on Ibn Majah's narration that this isnad is ḍa'îf (weak) because Hafṣ bin Sulaiman is a weak, and according to al-Suyutti this hadith has a weak isnad although it's meaning is valid. While according to Jamaluddin al-Mizzi this hadith is rated hasan, because of the many paths of transmission upon it (Ibn Mājah). Abu Bakar al-Bazār said that the entire transmission line that ended with Anas bin Malik on the text of this hadith is invalid (Al-Bazār, 2009).

6. The transmission of Ahmad bin Kholid al-Qurashi, he often delivers bātil (untrue) news (Ibn Hajar, 1971). One of the narration he distributes is: Khiyār Ummatī 'Ulamā'uhā wa Khiyār 'Ulamā'ihā Hulamā'uhā, Alā wa anna Allaha Yaghfir lī al- 'Ālim alRaHìm Arba'ìn Dhanban qabla an Yaghfira li al-Jāhil al-Mubadhir Dhanban Wāhidan. The hadith narrated by al-Qudla'i in Musnad al-Shihab from Muhammad Ibn Ismail al-Farghān̄̄ from al-Hākim from al-Hasan bin Muhammad bin Ishāq al-Azharī from Ahmad bin Khali alQurashi from Nūh bin Habīb from Ibn Maslamah from Malik from Nāfí' from Ibn Umar (AlQudā̄' $\overline{1}, 1986)$. No one of canonical book compiler narrated that hadith, Abu Nu'aim alAȘbihānī explains that the hadith is Gharib (Abū Nu'aim, 1974).

7. The transmission of Ahmad ibn Salman al-Armani al-Harānī. One of the hadith which he spread is: al-Nawm Hadath wa al-Ghishyān Hadath watra'ūna 'an Dhikr alFājir Udhkurūhu liya'rifahu al-Nās. This hadith narrated from Malik from Nāfi' from Ibn Umar, according to Ibn Hajar, that hadith is mawḍu' (false), because Ahmad ibn Sulayman was a liar and often delivered false news (Ibn Hajar, 1971).

8. The transmission of Ahmad bin Șulaih, he narrated from Dhu al-Nūn al-Mișrī from Malik from Nāfi' from Ibn Umar. According to Ibn Hajar it is wrong, because Ahmad can not be used as a basis (Ibn Hajar, 1971). One of hadith he distributes is: Iqtadū bi alLadhaini min Ba'd $\bar{\imath} A b \bar{\imath} B a k r$ wa 'Umar. This hadith is also written by al-Tirmidhi in his book with the transmission of al-Hasan bin al-Șabbāḥ al-Bazār from Sufyān bin 'Uyainah from Zā'idah from Abdul Malik Ibn 'Umair from Rib'iy from Hudhaifah from the Prophet and rated hasan by al-Tirmidhi (al-Tirmidhi, 1975). Many other hadith books mention this hadith too, but none of them used Ahmad bin Șulaị isnad from Dhu al-Nūn al-Mișri.

9. The transmission of Ahmad ibn Amr bin Faras bin Zanjawaih, he narrated from Hisham Ibn Ammar from Malik from Nāfi' from Ibn Umar, One of the hadith he spreaded is: Huwa al-Ṭaūru Mā'uhu wa al-Hillu Maytatuhu. According to al-Dāruquțn̄ this hadith is invalid with this isnad and the it has been changed, but he did not mentioned the wrong he mean, so al-Khatīb considers Ahmad bin 'Amr as reliable (Ibn Hajar, 1971). This hadith also found in Mālik's Muwațta' which is taught by Mustafa Azami with an isnad which culminates to Abu Hurairah (Malik, 2004).

10. The transmission of Ahmad ibn Muhammad ibn al-Șalt Ibn al-Mughlis alHamāni, he was a liar, One of the hadiths he distributed was: Raddu Dāniq min Harām Afḍal 'Inda Allah min Sab'ina Hajjah Mabrūrah. This hadith is narrated from Yahya bin Sulayman Ibn Naḍlah from Malik from Nâfi' from Ibn Umar, then he also mentions the hadith with a different narration and the text is partially converted to Hannād from Usāmah from Ubaidillah from Nāfi' from Ibn Umar, therefore Ibn Hibbaan called him as hadith forgerer (al-'Atamī, 1986).

11. The transmission of Ahmad ibn Muhammad ibn Imran Abu Ya'qub, One of hadith he spread is: Salātun fì Masjidī Hādhä Af̣̣al min Alfi Salāt. He narrated This hadith from Abdullah bin Nāfi' al-Șā'igh from Malik from Nāfi' from Ibn Umar. According to alDāruquṭni the hadith is not correct with this isnad because Ahmad Ibn Muhammad is unknown person (Ibn Hajar, 1971). In Sahih Muslim This hadith is recorded twice, first with narrations through 'Amr al-Nāqid and Zuhair bin Harb from Sufyān bin 'Uyainah from al-Zuhri from Sa'îd bin al-Musayyib from Abu Hurairah, second through Zuhair bin Ḥarb and Muhammad 
bin al-Muthannā from Yahya bin Sa'id al-Qatțān from Ubaidillah from Nāfi' from Ibn Umar from the Prophet (Muslim, 1993). In the six books and the hadith also recorded, but no compiller of those literature used Ahmad bin Muhammad bin 'Imrān isnad.

12. The transmission of Ahmad bin Yahya bin Zukair, he narrated from Muhammad bin Kamil from Malik from Nāfi' from Ibn Umar the following hadith: Law Anna Rajulan Șāma Nahārahu wa Qāma Lailahu Hasharahu Allahu 'Alā Niyyatih. According to al-Dāruquṭn this hadith is not true if using this isnad, because Ibn Kamil and Ibn Zukair is $d a^{\prime} \hat{\imath} f$ (weak) (Ibn Hajar, 1971). The author found this hadith recorded in al-Fawâ' $i d$ with isnad Malik from Nāfi' from Ibn Umar from Umar bin Khattāb (Abū al-Qāsim, 1412).

13. The transmission of Ishaq bin Ibrahim al-Ṭabarī, he narrated from Ubaidullah bin al-Walīd al-Kindī from Malik from Nāfi' from Ibn Umar the following hadith: $J \bar{a} a$ Rajulun ilā Rasūlillah fa Shakā ilaihi Daynan wa Faqran faqāla Aina Anta min Salāt alMalà'ikah. According to al-Dāruquṭī this is a munkar hadith and According to Ibn Hibban, Ishaq often conveys the mawdu' (false) hadith and relies it to the tsiqat - reliable person (Ibn Hajar, 1971).

14. The transmission of Ishaq bin Ismail al-Jawzajani, he narrated from Said bin Isa from Ma'n al-Ashjā'̄ from Malik from Nāfi' from Ibn Umar the following hadith: Min Mā Yași Laka Wa Li Akhīka al-Muslim an Takūna Fì Ghaybatihi Af̣̣ala Min Mā Takūnu Fō Maḥdarihi. According to al-Dāruquṭn̄ this hadith is invalid, because of all transmitters besides Malik are the weak person (Ibn Hajar, 1971). The author also do not find this hadith in other books.

15. The transmission of Ishāq bin Muhammad al-Bairūti, he narrated from Malik from Nāfi' from Ibn Umar this hadith: Ya Rasūlallah Ursil wa Atawakkal, Qāla Bal Qayyid wa Tawakkal. This hadith is narrated by Muhammad ibn Abd Rahman ibn Rīsān with that isnad and according to al-Dāruquṭn̄ these traditions include into munkar hadith (Ibn Hajar, 1971). The hadith is also found recorded in the book of Bahr al-Fawā'id with a narration from Ibrahim Ibn al-Mundhir, Abdullah Ibn Musa al-Taimī and Ya'qūb Ibn Abdillah, all of them accepted it from Ja'far bin 'Amr from 'Amr ibn Umayyah (al-Kalābādī, 1999), the author also found in the Shu'ab al-Īmān book with a narration from Abu Ja'far al-Mustamlī from Abu al-'Abbās Muhammad bin Ishāq al-Ḍabu'ī from al-Hasan bin Ali bin Ziyād from Ibrahim bin al-Mundhir from 'Amr bin Umayyah (Al-Baihaqī, 2003). So it is true what alDāruquțni said that this hadith does not use Malik's chain from Nāfi' from Ibn Umar.

16. The transmission of Ahmad bin Yazid al-Khurāsāni, he narrated from Muhammad bin Ja'far bin Muhammad bin Zaid from Yahya bin al-Khusain bin Zaid bin Ali from Ali bin Abdillah bin Muhammad bin Umar ibn Ali from Malik from Nāfi' from Ibn Umar the following hadith : Innahū Kāna Yaqūlu: al-Masjid al-Ladhi Ussisa 'Ala al-Taqwa Masjid Rasulillah. According to al-Dāruquțnī this hadith is not true from Malik from Nāfi', because Ahmad Ibn Yazid is not famous for his transmission (Ibn Hajar, 1971). This hadith is also recorded in the six canonical books, and which uses exactly the same text as the above is in Sahih Muslim with a narration from Muhammad bin Hātim from Yahya bin Sa'īd from Humaid al-Kharrāṭ from Abu Salamah from Abd Rahman bin Abī Sa'̄̄d from Abu Sa'îd al-Khudri (Muslim, 1993), so this supports al-Dāruquṭi's statement that This hadith is not correct using an isnad delivered by Ahmad bin Yazìd.

\section{Conclusion}

Based on the discovery of the Lisān al-Mīzān book regarding the golden chain of Malik from Nāfi' from Ibn Umar, found some traditions that are also recorded in the six canonic books (kutub sittah) and other hadith literatures. These hadiths recorded in the canonical books did not use an isnad of peoples who are considered weak by Ibn Hajar who partially cite the opinion of al-Dāruquțī. Thus it can be concluded that Muslim scholars, by 
using existing methods of hadith criticism have been able to separate authentic hadiths from the weak one, and if those traditions are still written in reliable books, then its transmission used a credible narrators.

\section{References}

Abū al-Qāsim, T. b. 1412. al-Fawā'id. Riyad: Maktabah al-Rushd.

Abū Nu'aim, a.-A. 1974. Hilyah al-Awliyā' wa Tabaqāt al-Așfiyā'. Mesir: al-Sa'ādah.

al-'Atamī, A. R.-M. 1986. al-Tankīl bimā fì Ta'nīb al-Kawtharī min al-Abāțīl. Bairut: alMaktab al-Islāmī.

Brown, J. 2007. Critical rigor vs juridical pragmatism, how legal theoritists and hadith scholar approached the backgrowth of isnad in the genre of 'ilal al-Hadith. Islamic Law and Society.

Al-Baihaqī. 2003. Shu'ab al-Īmān. Bombai: Maktabah al-Rushd.

Al-Bazār, A. B.-K.-`. 2009. Musnad al-Bazār al-Manshūr bi-Ismi al-Bahr al-Zakhār. Madinah: Maktabah al-'Ulūm wa al-Hikam.

al-Bukhari. n.d.. al-Tārīkh al-Kabīr

al-Hamdhān̄̄, Y. b.-M. 2002. al-Mahrūniyyāt: al-Fawāid al-Muntakhabah al-Ṣiḥhah wa alGharīb. Madinah: al-Jāmi'ah al-Islāmiyyah.

Ibn Hajar, a.-'. 1971. Lisān al-Mīzān. Bairut: Mu'assasash al-A'lamī li al-Mațbū'āt.

Ibn Mājah, M. b.-Q. n.d. Sunan Ibn Mājah. Bairut: Dār Ihyā' al-Kutub al-'Arabiyyah. Ibn Șalāḥ, U. b. 1986. Ma'rifah anwā' 'Ulum al-Hadith. Bairut: Dār al-Fikr.

Al-'Iraqy, Z. A.-H. n.d.. Tarh al-Tathrīb fì Sharh al-Taqrīb : Taqrīb al-Asānīd wa Tartīb al-Masānīd. Bairut: Dār al-Fikr al-'Arabī.

Juynboll, GHA. 1985. Muslim Traditions: Studies in Chronology provenance and Authorship of Early Hadìth. Cambridge: Cambridge University Press.

al-Kalābādī, A. B. 1999. Baḥr al-Fawā'id al-Mashhūr bi Ma'ānī al-Akhbār. Bairut: Dār alKutub al-'Ilmiyyah.

Malik, I. A. 2004. Muwaț̣a' Mālik. Emirat: Mu'assasah Zāyid bin Sulțān.

Muslim, b. a.-H. 1993. Șahih Muslim. Bairut: Dār Iḥyā’ al-Turath al-‘Arabī.

Al-Nasā'1̄, A. b. 1986. al-Sunan al-Sughra. Halb: Maktab al-Maṭū'ât al-Islāmiyyah.

al-Nawawī, Y. b. 1985. Al-Taqrīb wa al-Taisīr li Ma'rifat Sunan al-Bashīr al-Nadhīr fì Ușul al-Hadīth. Bairut: Dār al-Kitāb al-'Arabī.

Al-Quḍā'̄̄, A. A. 1986. Musnad al-Shihāb. Bairut: Mu'assasah al-Rsālah.

al-Ṣan'ānī, A. R. 1403. al-Mușannaf. Bairut: al-Maktab al-Islāmī.

Al-Tabrānī. 1994. al-Mu ’jam al-Kabìr. Kairo: Maktabah IbnTaimiyyah. Al-Ṭabrānī. n.d. alMu'jam al-Awsat. Kairo: Dār al-Haramain.

al-Tirmidhi, M. b.-D. 1975. Sunan al-Tirmidhi. Mesir: Shirkah Maktabah wa Maṭba'ah Muștafâ al-Bābī. 